\title{
Production components, grain yield and water use efficiency of irrigated cowpea
}

\author{
João Irene Filho', Aderson Soares de Andrade Júnior²*, José Orlando Piauilino Ferreira ${ }^{3}$, \\ Flávio Favaro Blanco ${ }^{2}$, Milton José Cardoso ${ }^{2}$
}

\author{
Federal University of Piauí - Cinobelina Elvas Campus, Bom Jesus, PI, Brazil \\ ${ }^{2}$ Embrapa Mid - North, Teresina, PI, Brazil \\ ${ }^{3}$ Bom Jesus Agriculture High School, Bom Jesus, PI, Brazil \\ ${ }^{*}$ Corresponding author, e-mail: aderson.andrade@embrapa.br
}

\begin{abstract}
Cowpea cultivars, which are indicated for irrigated cropping, are recommended without proper assessment of their productive potential and water use efficiency in response to water regimes in the soil from different production environments. The aim of this study was to evaluate the production components, the yield performance and the efficiency of water use of cowpea cultivars in response to the application of irrigation depths under the soil and climate conditions of Bom Jesus, PI. The experiment was performed from June to August 2011 in a soil classified as sandy-textured Fluvic Neosol. The study was conducted in a randomized blocks design, with four replicates. The treatments were arranged in subdivided plots (irrigation depths in plots and cultivars in subplots). The cultivars BRS Aracê (semi-prostrate) and BRS Tumucumaque (semierect) were submitted to five irrigation depths (108.2, 214.7, 287.9, 426.1 and $527.7 \mathrm{~mm}$ ). The number of pods per plant and the weight of one hundred grains are the main components related to grain yield. The cultivar BRS Tumucumaque presented a better yield performance (1697.2 $\left.\mathrm{kg} \mathrm{ha}^{-1}\right)$ than the cultivar BRS Aracê $\left(1233.8 \mathrm{~kg} \mathrm{ha}^{-1}\right)$, with the application of the irrigation depths of 527.7 and $522.4 \mathrm{~mm}$, respectively. The highest water use efficiency $\left(0.420 \mathrm{~kg} \mathrm{~m}^{-3}\right)$ is obtained with the application of the irrigation depth of $108.2 \mathrm{~mm}$ in both cultivars.
\end{abstract}

Keywords: Vigna unguiculata, irrigation management, water balance

\section{Introduction}

Irrigation is a viable alternative to improve the cowpea (Vigna unguiculata (L.) Walp.) yield in the Brazilian semi-arid region due to the irregular rainfall in this region. According to Capra \& Scicolone (2007), the irrigation is responsible for the consumption of 50 to $85 \%$ of the available water resources in semi-arid areas. In traditional and high technology production systems, it is essential to know the modifications in the production components and grain yield of modern cultivars in response to the application of irrigation (Bezerra et al., 2009).

To obtain higher yields of cowpea it is necessary to adopt good management practices aimed at improving the efficiency of irrigation. According to Bastos et al. (2008), considering the phenological stages of cowpea, the reproductive period (flowering and grains filling) constitutes the stage of higher water demand. The new cultivars of cowpea usually present a high response to irrigation; however, they are recommended without proper assessment of their productive potential and water use efficiency under different conditions of water availability in the soil.

To increase crop yield, reduce production costs and increase farmers' income, it is essential to adopt technologies such as an adequate management of irrigation and fertilization (Oliveira et al., 2011). However, the average 
grain yield $\left(1,200.0 \mathrm{~kg} \mathrm{ha}^{-1}\right)$ in this regime is below the average that could be obtained with adequate management during the vegetative and reproductive phases. This information was confirmed by Souza et al. (2011), who studied the water use efficiency of corn and cowpea crops under exclusive and intercropping systems in the Brazilian semi-arid region. They concluded that the cowpea crop responds positively to irrigation water application.

According to Mousinho et al. (2008), the irrigated cultivation of cowpea in the state of Piauí is viable, regardless of the date of sowing and water capacity available in the soil. However, it is necessary to define optimal irrigation depths and evaluate their impacts on the production components, grain yield and water use efficiency under the specific soil and climate conditions of each production environment.

Therefore, the aim of this study was to evaluate the production components, grain yield and water use efficiency of two cowpea cultivars submitted to irrigation depths under the soil and climate conditions of Bom Jesus, Piaui.

\section{Materials and Methods}

The experiment was carried out at Sitio São Luiz, located at $3 \mathrm{~km}$ from Bom Jesus- Pl

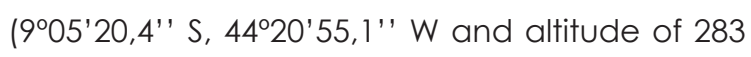
$\mathrm{m})$, from June to August, 2011, in a soil classified as fluvic Neosol (Embrapa, 2006). The average annual rainfall is defined by the continental equatorial regime, with annual isohyets around 700 to $1,200 \mathrm{~mm}$. The rainy season extends from November to May, and January, February and March are considered the wettest quarter. According to Thornthwaite \& Mather (1955), the region climate is defined as dry sub-humid (Andrade Júnior et al., 2004).

To define the fertility levels and the physical-water characteristics of the soil, ten simple and deformed soil samples were collected for each composite sample, in the layers of 0 to $0.2 \mathrm{~m}$ and 0.2 to $0.4 \mathrm{~m}$. Soil preparation was performed through plowing and harrowing which were sufficient for adequate soil disruption. Basic (45 $\mathrm{kg} \mathrm{ha}^{-1} \mathrm{P}_{2} \mathrm{O}_{5}$ and $40 \mathrm{~kg} \mathrm{ha}^{-1} \mathrm{~K}_{2} \mathrm{O}$ ) and topdressing fertilization $\left(30 \mathrm{~kg} \mathrm{ha}^{-1} \mathrm{~N}\right)$, performed 15 days after emergence, were carried out based on the chemical analysis of the experimental area (Table 1), following the nutritional requirements of cowpea (Embrapa, 2003). Two months before sowing, liming was performed with the application of $1 \mathrm{Mg} \mathrm{ha}^{-1}$ dolomitic limestone.

Table 1. Soil chemical analysis of the experimental area. Bom Jesus, PI, 2011.

\begin{tabular}{|c|c|c|c|c|c|c|c|c|c|c|c|c|c|}
\hline \multirow{2}{*}{$\begin{array}{l}\text { Depth } \\
\text { (m) }\end{array}$} & \multirow{2}{*}{$\begin{array}{l}\mathrm{OM} \\
\mathrm{g} / \mathrm{kg}\end{array}$} & \multirow{2}{*}{$\begin{array}{l}\mathrm{pH} \\
\mathrm{H}_{2} \mathrm{O}\end{array}$} & \multirow{2}{*}{$\begin{array}{c}P \\
\left(\mathrm{mg} / \mathrm{dm}^{3}\right)\end{array}$} & K & $\mathrm{Ca}$ & $\mathrm{Mg}$ & $\mathrm{Na}$ & $\mathrm{Al}$ & $\mathrm{H}+\mathrm{Al}$ & $S$ & CEC & \multirow{2}{*}{\multicolumn{2}{|c|}{$\begin{array}{l}\mathrm{V} \quad \mathrm{m} \\
----\end{array}$}} \\
\hline & & & & & \multicolumn{6}{|c|}{$\left(\mathrm{mmol}_{\mathrm{c}} / \mathrm{dm}^{3}\right)$} & & & \\
\hline $0.0-0.2$ & 3.69 & 5.27 & 7.83 & 0.14 & 0.57 & 0.39 & 0.02 & 0.15 & 2.07 & 1.14 & 3.22 & 35.56 & 10.28 \\
\hline $0.2-0.4$ & 1.14 & 4.97 & 2.06 & 0.05 & 0.16 & 0.28 & 0.02 & 0.20 & 1.71 & 0.52 & 2.24 & 23.41 & 27.83 \\
\hline
\end{tabular}

The experiment was conducted in a complete randomized block design, with treatments arranged in subdivided plots (irrigation depths in the plots and cultivars in the subplots). Each block consisted of five plots of $12 \times 12 \mathrm{~m}$, where the irrigation depths were arranged. Each subplot (cultivars) of $6 \times 12 \mathrm{~m}$ from which the plants were removed for production evaluations and production components.

Two manual weedings mantained the experimental area free and allowed the fully establishment of the crop. The phytosanitary treatment was performed with two insecticide applications (mixture of Fention (Lebaycid 500) +
Abamectin (Vertimec 50), 28 days after planting (DAP); and a fungicide application (RECOP copper oxychloride) 35 DAP.

The cultivars BRS Aracê (semi prostrate) and BRS Tumucumaque (semi erect) were evaluated. Sowing was carried out on June 17, 2011, with a manual planter, with $0.8 \mathrm{~m}$ between rows. Fifteen days after sowing, thinning was performed in the rows of plants, leaving five plants per linear meter. The irrigation system was set up with sprinklers, $12 \times 12 \mathrm{~m}$ spaced, with irrigation depths based on the daily reference evapotranspiration (ETo), determined by the Penman - Monteith method (FAO - 56) (Allen et al., 
1998 ) based on the percentages of $30 \%$ (Range 1), 60\% (Range 2), 90\% (Range 3), 120\% (Range 4) and $150 \%$ (Range 5) arranged randomly in the field. The climatic data of air temperature, relative air humidity, wind speed and global solar radiation, in which ETo was estimated and precipitation recorded during the experimental period were obtained from the INMET automatic agrometeorological station installed at UFPI, $1 \mathrm{~km}$ far from the experimental area.

The irrigation depths were applied following a fixed irrigation shift. To adjust the irrigation to soil water storage capacity, irrigation ranges 1, 3 and 5 were irrigated every Monday, Wednesday and Friday. Thus, on Monday, it was apllied the ETo accumulated on Friday, Saturday and Sunday; on Wednesdays, the ETo accumulated on Monday and Tuesday and on Fridays, the ETo accumulated on Wednesday and Thursday. For the ranges 2 and 4, on Tuesday, it was applied the the ETo accumulated on Saturday, Sunday and Monday; on Thursdays, the ETo accumulated on Tuesday and Wednesday and, on Saturdays, the ETo accumulated on Thursday and Friday. The differentiated irrigation depths were applied after 24 days of sowing, and this procedure was adopted for the stabilization of the crop in the first days after germination.

The uniformity evaluation of the application of water regimes was made through the installation of a mesh of twelve PVC collectors, $3 \times 3 \mathrm{~m}$ spaced, in the central portion of all irrigation ranges. The coefficient of uniformity of Christiansen (CUC) was estimated with the volumes collected at the end of each irrigation (Frizzone, 1992). The water content of the soil was monitored using the gravimetric method, where soil samples were collected at depths of 0 to 0.2 and 0.2 to $0.4 \mathrm{~m}$ with three replicates within each irrigation range. These samples were immediately taken to the laboratory, weighed and taken to the oven for drying during 48 hours. The collections were performed 24 hours before and after the irrigation to assess the maximum and minimum values of water content in the soil, imposed with the application of each irrigation range, throughout the crop cycle.

The production components were: number of pods per plant (NPP), pod length (PL, cm), number of grains per pod (NGP), weight of one hundred grains (W100G, g), pod yield $\left(\mathrm{Kg} \mathrm{ha}^{-1}\right)$, grain yield (GY, $\mathrm{kg} \mathrm{ha}^{-1}$ ) and water use efficiency (WUE, $\mathrm{kg} \mathrm{m}^{-3}$ ). The WUE was obtained by the ratio between GY $\left(\mathrm{kg} \mathrm{ha}^{-1}\right)$ and the applied irrigation depth $\left(\mathrm{m}^{3} \mathrm{ha}^{-1}\right)$.

Before the statistical analysis, a residue analysis was performed for all the characters to evaluate the existence of discrepant data, heteroscedasticity of variance, adjustment of the errors to an approximately normal distribution (Nogueira, 2007). The regression was used in the analysis of variance following the method proposed by Garcia et al. (2002), Pimentel-Gomes (2000), Zimmermann (2004). The Tukey's test was applied at $5 \%$ probability for the comparison of the means related to the cultivar factor.

\section{Results and Discussion}

Mean and total decendial values of air temperature, relative air humidity, solar radiation, wind speed and precipitation during the experiment were $26.50^{\circ} \mathrm{C}, 46.72 \%, 76.5 \mathrm{MJ} \mathrm{m}{ }^{-2}$, $1.47 \mathrm{~m} \mathrm{~s}^{-1}$ and $0.0 \mathrm{~mm}$, respectively. At the end of the cultivation cycle, the irrigation depths were 108.2 (D1), 214.7 (D2), 287.9 (D3), 426.1 (D4) and $527.7 \mathrm{~mm}$ (D5) (Table 2). It is worth mentioning that during the experimental period there was no rainfall, so that the productive response occurred only due to the irrigation depths.

As the differentiation of the irrigation depths was only imposed after 24 days after sowing (DAS), it was not observed sensible variations in water content in the soil with their application during this period. However, after this period, there was a gradual increase of the irrigation depths, as a consequence of the accumulated application of ETo replacement during the experimental period (Figure 1). In the pre-flowering phenological phase of cowpea, the occurrence of water deficiency in the soil does not result in a high reduction of grain yield, ensuring a certain mechanism of adaptation to drought in some genotypes (Santos et al., 2010).

Among the evaluated components, only the pod length (PL) did not respond to irrigation, cultivars and interaction (Table 3). It can be inferred that there were no water deficit situations that affected this component of production. 
Filho et al. (2017) / Production components, grain yield ...

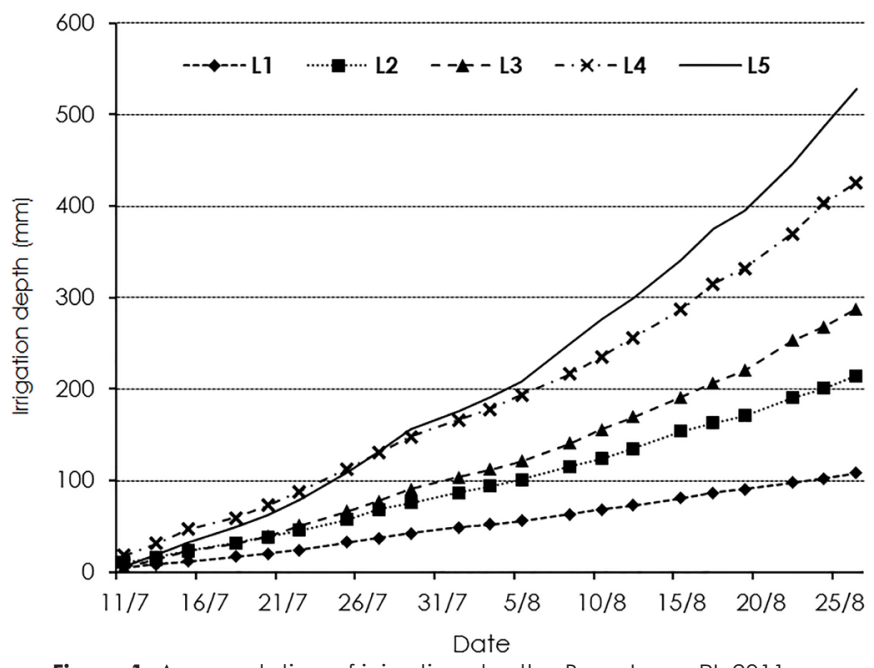

Figure 1. Accumulation of irrigation depths. Bom Jesus, PI, 2011.

Table 3. Mean square of the production components and water use efficiency as a function of the irrigation depths applied in cowpea cultivars. Bom Jesus, PI, 2011.

\begin{tabular}{|c|c|c|c|c|c|c|c|c|}
\hline \multirow{2}{*}{ SV } & \multicolumn{8}{|c|}{ Mean Square } \\
\hline & DF & NPP & $\mathrm{PL}$ & NGP & WIO0G & PY & GY & WUE \\
\hline Block & 3 & $0,1625 *$ & $2,9242^{\mathrm{ns}}$ & $0,0087^{\mathrm{ns}}$ & $0,742^{\text {ns }}$ & $232583,22 * *$ & 103684,553 ns & $0,012^{\mathrm{ns}}$ \\
\hline Depths (D) & 4 & $2,0026^{* *}$ & $1,6081 \mathrm{~ns}$ & $0,1067 * *$ & $6,145 * *$ & $2952446,66^{* *}$ & $1282936,643^{* *}$ & $0,030^{\text {ns }}$ \\
\hline Error (a) & 12 & 0,1034 & 1,2219 & 0,0408 & 1,277 & 105911,24 & 61833,714 & 0,015 \\
\hline Cultivar (C) & 1 & $0,7853^{* *}$ & 1,4062 ns & $0,2339 * *$ & $160,801 * *$ & $306241,25^{* *}$ & $203088,151 *$ & $0,012^{\text {ns }}$ \\
\hline D versus C & 4 & $0,0835^{\mathrm{ns}}$ & 0,8019 ns & $0,0230 \mathrm{~ns}$ & $4,736 *$ & 92914,16 * & 86826,379 ns & $0,003^{\text {ns }}$ \\
\hline Error(b) & 15 & 0,0461 & 1,0307 & 0,0192 & 0,987 & 28294,58 & 31775,510 & 0,005 \\
\hline C.V (\%) & & 7,9500 & 5,318 & 3,981 & 4,903 & 12,37 & 17,715 & 20,930 \\
\hline
\end{tabular}

Tagliaferre et al. (2013), studying the agronomic characteristics of cowpea related to irrigation depths and nitrogen levels, did not observe variation in this production component. A similar situation was observed by Oliveira et al. (2011) who studied the response of cowpea to irrigation depths and phosphorus doses in Roraima. Studying cowpea yield in Paraiba, Santos (2013) reported that the cultivar BRS Marataoã did not differ statistically from cultivars BRS Potiguar and Miranda IPA-207, where the overall mean of this variable was $18.65 \mathrm{~cm}$. That result was similar to the ones found in this study $(19.08 \mathrm{~cm}$ ) (Table 4).

The NPP, NGP and GY varied in response to the irrigation (D) and cultivar (C) factors separately; while the W100G and PY showed significant interaction $(p<0.05$ ) between the two factors. The WUE for grain production of the cultivars did not vary significantly $(p<0.05)$ (Table 4$)$. The cultivar BRS Tumucumaque was superior to BRS Aracê for NPP (8.08) and W100G (22.26 g), which guaranteed higher average in pod yield $\left(1447.3 \mathrm{~kg} \mathrm{ha}^{-1}\right)$ and grain yield (1077.48 $\mathrm{kg} \mathrm{ha}^{-1}$ ) (Table 4), regardless the irrigation depth. Semi-erect cultivars have a superior productive potential in relation to the semi-prostates because they present leaf and shoot architecture which favors the capture of solar radiation by the plant, increasing the efficiency of the physiological and metabolic processes (Cardoso et al. ., 2005). NPP is the main responsible for the expression of grain yield in cowpea (Cardoso \& Ribeiro, 2013).

The variation of the production components, pod yield, grain yield and water use efficiency in response to the application of the irrigation depths in the cultivars BRS Aracê and BRS Tumucumaque are shown in Figure 2, whose regression equations and respective $R^{2}$ are found in Table 5.

The number of pods per plant increased linearly with the increase of irrigation depth for both cultivars (Figure 2A). However, the cultivar BRS Tumucumaque presented higher NPP than the cultivar BRS Aracê in all irrigation depths. The increases were linear and showed that the largest irrigation depth $(527.7 \mathrm{~mm})$ provided the 
Table 4. Number of pods per plant (NPP), pod length (PL, cm), number of grains per pod (NGP), weight of one hundred grains (P100G, g), pod yield (PY, $\left.\mathrm{kg} \mathrm{ha}^{-1}\right)$, grain yield $\left(\mathrm{GY}, \mathrm{kg} \mathrm{ha}^{-1}\right.$ ) and water use efficiency $\left(\mathrm{WUE}, \mathrm{kg} \mathrm{m}^{-3}\right)$. Bom Jesus, PI, 2011.

\begin{tabular}{llllllll}
\hline \multicolumn{1}{c}{ Cultivar } & NPP & W100G & PL & NGP & PY & GY & WUE \\
\hline BRS Aracê & $6.56 \mathrm{~b}$ & $18.25 \mathrm{~b}$ & $18.90 \mathrm{a}$ & $12.68 \mathrm{a}$ & $1272.3 \mathrm{~b}$ & $934.97 \mathrm{~b}$ & $0.329 \mathrm{a}$ \\
BRS Tumucumaque & $8.08 \mathrm{a}$ & $22.26 \mathrm{a}$ & $19.27 \mathrm{a}$ & $11.53 \mathrm{~b}$ & $1447.3 \mathrm{a}$ & $1077.48 \mathrm{a}$ & $0.364 \mathrm{a}$ \\
\hline Overall mean & 7.32 & 20.25 & 19.08 & 12.10 & 1359.8 & 1006.22 & 0.347 \\
\hline
\end{tabular}

Means followed by the same letter do not differ from each other at $5 \%$ probability by the Tukey's test
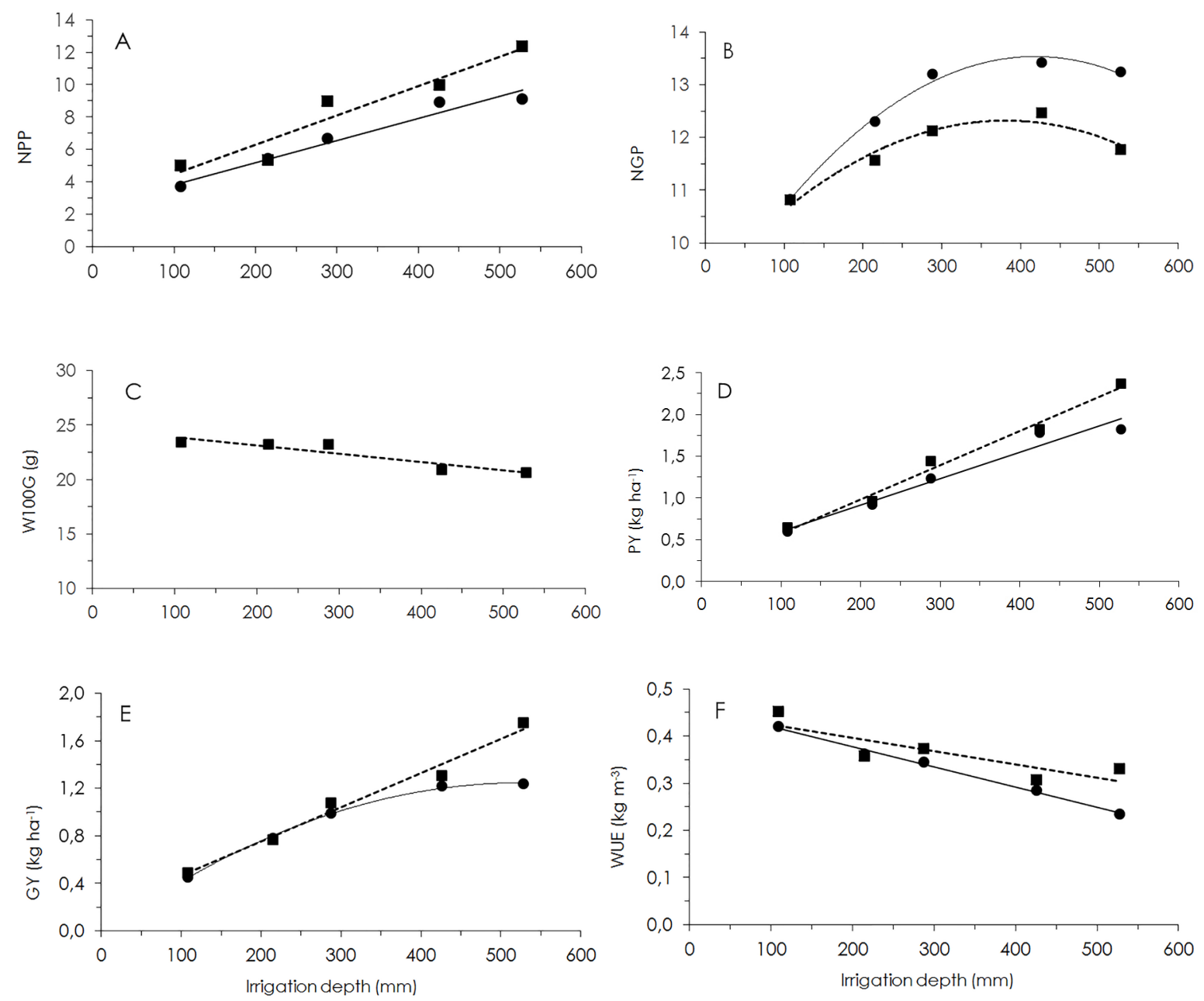

Figure 2. Number of pods per plant (A), number of grains per pod (B), weight of 100 grains (C), pod yield (D), grain yield (E) and water use efficiency (F) over the irrigation depths applied in BRS Aracê (•) and BRS Tumucumaque (घ). Bom Jesus, PI. 2011.

highest values of NPP $(9.7$ for BRS Aracê and 12.2 for BRS Tumucumaque) (Table 5), indicating that probably larger irrigation depths would be needed to increase the availability of water in the soil to reach maximum NPP values, probably because it is a sandy soil with a low water retention capacity.

There was a reduction of $59.81 \%$ and $59.68 \%$ in the NPP with the reduction of the largest irrigation depth $(527.7 \mathrm{~mm})$ and for the shortest depth $(108.2 \mathrm{~mm})$ for the cultivars BRS Aracê and BRS Tumucumaque, respectively. In a study in Cariri Paraibano, with the cultivar EPACE-10, Santos et al. (2009) obtained higher values for NPP (16.4), indicating that it is an inherent component of each cultivar depending on the management, soil and climate conditions of the growing regions.

The cultivar BRS Aracê presented better performance than the cultivar BRS Tumucumaque in relation to NGP (Figure 2B). The maximum values obtained for NGP were 13.2 (BRS Aracê) and 12.6 (BRS Tumucumaque), with the application of the optimal irrigation depths 
Table 5. Regression equations and respective $R^{2}$ for number of pods per plant (NPP), pod length (PL, cm), number of grains per pod (NGP), weight of 100 grains (w100G, g), pod yield (PY, $\left.\mathrm{kg} \mathrm{ha}^{-1}\right)$, grain yield $\left(\mathrm{GY}, \mathrm{kg} \mathrm{ha}^{-1}\right)$ and water use efficiency (WUE, $\mathrm{kg} \mathrm{m}^{3}$ ) over irrigation depths ( $\mathrm{D}, \mathrm{mm}$ ) for BRS Aracê and BRS Tumucumaque. Bom Jesus, PI, 2011.

\begin{tabular}{|c|c|c|c|c|c|c|}
\hline Cultivars & Equations & $x$ & $\mathrm{Y}$ & $\mathrm{Xmax}$ & Ymax & $\mathrm{R}^{2}$ \\
\hline \multirow{4}{*}{ BRS Aracê } & $\mathrm{NPP}=2.474^{* *}+0.0136 \mathrm{~L}^{* *}$ & 527.7 & 9.7 & \multirow{3}{*}{391.7} & \multirow{3}{*}{13.2} & 0.9581 \\
\hline & NGP $=8.626^{*}+0.023 L^{* *}-0.3 \times 10^{-4} L^{2 * *}$ & & & & & 0.9910 \\
\hline & $P Y=281.848^{\text {ns }}+3.1652 L^{* *}$ & 527.7 & 1952.1 & & & 0.9644 \\
\hline & $\begin{array}{l}\text { GY }=-21.546^{* *}+4.806 L^{* *}-0.0046 L^{2 * *} \\
\text { WUE }=0.4631^{\text {ns }}-0.0004 L^{* *}\end{array}$ & 527.7 & 0.252 & 522.4 & 1233.8 & $\begin{array}{l}0.9980 \\
0.9938\end{array}$ \\
\hline \multirow{5}{*}{ BRS Tumucumaque } & $\begin{array}{l}\mathrm{NPP}=2.6647^{* *}+0.0181 \mathrm{~L}^{* *} \\
\mathrm{NGP}=9.195^{*}+0.016 \mathrm{~L}^{* *}-0.2 \times 10^{-4} \mathrm{~L}^{2 * *}\end{array}$ & 527.7 & 12.2 & \multirow{5}{*}{410.0} & \multirow{5}{*}{12.6} & 0.9245 \\
\hline & $\mathrm{W} 100 \mathrm{G}=24.673^{* *}-0.0077 \mathrm{~L}^{* *}$ & 108.2 & 23.8 & & & 0.8650 \\
\hline & $P Y=165.260^{\text {ns }}+4.097 \mathrm{~L}^{* *}$ & 527.7 & 2327.2 & & & 0.9864 \\
\hline & $G Y=174.590^{\text {ns }}+2.8854 L^{* *}$ & 527.7 & 1697.2 & & & 0.9823 \\
\hline & WUE $=0.4521^{\mathrm{ns}}-0.0003 L^{* *}$ & 527.7 & 0.294 & & & 0.7215 \\
\hline
\end{tabular}

of $391.7 \mathrm{~mm}$ and $410 \mathrm{~mm}$, respectively (Table 5). The overall mean for NGP was 12.68 for BRS Aracê and 11.53 for BRS Tumucumaque (Table 2).

Silva \& Neves (2011), analyzing the production components and their correlations in cowpea genotypes in rainfed and irrigated crops, found a mean value for NGP of 15.91 . However, Matos Filho et al. (2009) analyzing the productive potential of erect cowpea progenies, observed an overall mean for NGP lower than those observed in this study (7.15 grains per pod). As the PL did not vary with the application of the irrigation depths, the NGP becomes dependent only on the W100G.

In study about population density, with IT87D-611-3 (erect), Bezerra et al. (2009) concluded that the regression analysis revealed non-significant F values for W100G in relation to plant population and row spacing, corroborating with the trend observed in this study for BRS Aracê cultivar. However, for BRS Tumucumaque, the variation of W100G in response to the application of the irrigation depths was adjusted to a linear polynomial equation (Figure $2 \mathrm{C}$ ). The irrigation depth which provided the highest W100G (23.4 g) was $108.2 \mathrm{~mm}$ (Table 5).

There was a decrease in W100G with the increase in soil water availability due to the increasing application of the irrigation depths, indicating that, for this cultivar, there is a compensation between W100G and NGP. In other words, the higher the NGP the lower the WI00G. In a study of irrigation depths versus nitrogen levels in cowpea, Tagliaferre et al (2013) observed that the lowest W100G values were close to the results found by other researchers $(23.5 \mathrm{~g})$, close to the highest W100G obtained in the present research (23.4 g) (Table 5).

Results similar to those observed by Santos et al. (2009), were observed for EPACE-10 (20.1g), in a study with cowpea varieties in the micro-region of Cariri Paraibano.

For both cultivars, PY was adjusted to an increasing linear function in response to the irrigation depths (Figure 2D), a trend that was also observed by Ferreira et al. (2010). For BRS Aracê (1952.1 kg ha-1) and BRS Tumucumaque $\left(2327.2 \mathrm{~kg} \mathrm{ha}^{-1}\right)$, the highest PY was obtained with the largest irrigation depth (527.7 mm) (Table 5), indicating that this one has greater productive potential, due to the superiority in terms of NPP and W100G.

The lowest PY for BRS Aracê was obtained with the application of $108.2 \mathrm{~mm}\left(591.1 \mathrm{~kg} \mathrm{ha}^{-1}\right)$, which represents a reduction of $69.7 \%$ in relation to the PY obtained with the application of the largest irrigation depth (1952.1 $\left.\mathrm{kg} \mathrm{ha}^{-1}\right)$, whereas with BRS Tumucumaque this reduction was much higher (72.4\%).

The highest PY values obtained with the application of the largest irrigation depth (527.7 mm) for both cultivars were lower than the average obtained by Andrade Junior et al. (2000) who, when evaluating the effects of applying different irrigation depths in cowpea cultivars in Parnaíba-PI, reached maximum PY values of $3389.5 \mathrm{~kg} \mathrm{ha}^{-1}$ applying irrigation depth of $394.4 \mathrm{~mm}$. These differences are due to the distinct productive potential of the cultivars, as well as the management practices which are 
adopted (Cardoso et al., 2005).

The GY showed a quadratic behavior for BRS Aracê and linear for BRS Tumucumaque with increasing application of irrigation depths (Figure 2E). The cultivar BRS Aracê presented maximum GY (1233.8 $\left.\mathrm{kg} \mathrm{ha}^{-1}\right)$ with application of the 522.4 $\mathrm{mm}$ (Table 5). A similar result was observed by Gualter et al. (2008), for the cultivar BRS Guariba irrigated by conventional spraying, with GY of $1174 \mathrm{~kg} \mathrm{ha}^{-1}$.

The highest grain yield for the cultivar BRS Tumucumaque was $1697.2 \mathrm{~kg} \mathrm{ha}^{-1}$, with an irrigation depth of $527.7 \mathrm{~mm}$ (Table 5). On the other hand, the lowest GY for this cultivar was $486.8 \mathrm{~kg} \mathrm{ha}^{-1}$, with application of $108.2 \mathrm{~mm}$ (Figure 2E). There was a reduction of $71.3 \%$ in GY with the reduction of the largest irrigation depth (D5) to the shortest (D1), due to the decrease in water content in the soil (from $15 \%$ to $7 \%$ ), as well as water availability (from $88 \%$ to $24 \%$ ) and reduction of soil water potential (from $-11 \mathrm{kPa}$ to $-80 \mathrm{kPa}$ ) (Table 2). The cultivar BRS Tumucumaque responded to the application of more frequent irrigation depths and keept the water content in the soil close to the total available water, as observed by Machado et al. (2008).

The values of WUE obtained with the application of the largest irrigation depth (527.7 $\mathrm{mm}$ ) were 0.252 and $0.294 \mathrm{~kg} \mathrm{~m}^{-3}$, whereas for the shortest irrigation depth $(108.2 \mathrm{~mm})$ it was 0.420 $\mathrm{kg} \mathrm{m}^{-3}$, for BRS Aracê and BRS Tumucumaque, respectively (Figure 2F). That is, the WUE is higher with the application of shorter irrigation depths, corroborating with Andrade et al. (2008), when reporting that the increase of the applied irrigation depth causes a reduction in the GY by promoting the leaching of nutrients from the soil.

BRS Tumucumaque is more efficient in the conversion of water to grains than BRS Aracê, since with the same volume of applied water it produces more grains (Figure 2E and 2F), due to its greater productive potential. Close values of WUE in cowpea cultivars (mean of $0.520 \mathrm{~kg} \mathrm{~m}^{-3}$ ) were obtained by Cardoso \& Melo (2010). The WUE tends to decrease with the increase of the applied water depth (Souza et al., 2011). These authors observed that although the irrigation of $100 \%$ of ETo provided higher grain yield, the water use efficiency analysis showed that the depth of $75 \%$ was more efficient, with $0.313 \mathrm{~kg}$ $\mathrm{m}^{-3}$ of applied water.

\section{Conclusions}

The number of pods per plant and the weight of one hundred grains are the main factors related to grain yield. The cultivar BRS Tumucumaque presented a better yield performance $\left(1697.2 \mathrm{~kg} \mathrm{ha}^{-1}\right)$ than BRS Aracê (1233.8 $\left.\mathrm{kg} \mathrm{ha}^{-1}\right)$, with the application of irrigation depths of 527.7 and $522.4 \mathrm{~mm}$, respectively. The highest water use efficiency $\left(0.420 \mathrm{~kg} \mathrm{~m}^{-3}\right)$ is obtained with the application of the irrigation depth of $108.2 \mathrm{~mm}$ in both cultivars.

\section{References}

Allen, R.G., Pereira, L.S., Raes, D., Smith, M. 1998. Crop evapotranspiration: Guidelines for computing crop water requirements. Irrigation \& Drainage (Paper 56. UN-FAO) 300: p.328.

Andrade Júnior, A.S., Rodrigues, B.H.N., Bastos, E.A. 2000. Irrigação. In: Cardoso, M.J.A. (ed.) cultura do feijão-caupi no Meio-Norte do Brasil. Embrapa Meio-Norte, Teresina-PI, Brasil. 264 p.11.

Andrade, E.M., Palácio, H.A.Q., Souza, I.H., Leão, R.A.O., Guerreiro, M.J. 2008. Land use effects in groundwater composition of an alluvial aquifer (Trussu River, Brazil) by multivariate techniques. Environmental Research106:170-177.

Bastos, E.A., Ferreira, V.M., Silva, C.R., Andrade Júnior. A.S. 2008. Evapotranspiração e coeficiente de cultivo do feijão-caupi no Vale do Gurgueia, Piauí. Irriga 13: 182-190.

Bezerra, A.A.C., Távora, F.J.A.F., Filho, F.R.F., Ribeiro, V.Q. 2009. Características de dossel e de rendimento em feijão-caupi ereto em diferentes densidades populacionais. Pesquisa Agropecuária Brasileira 44: 1239-1245.

Cardoso, M.J.; Melo, F.B. Produtividades de grãos secos e componentes de rendimento de cultivares comercial de feijão-caupi sob irrigação. 2010. In: Reunião Brasileira de Manejo e Conservação do Solo e da Água, 18., Resumos. Teresina: Embrapa Meio-Norte: Universidade Federal do Piauí, 2010. 4 p (CD-ROM).

Cardoso, M.J.; Ribeiro, V.Q. Produtividade de grãos e eficiência de uso da água em variedades comerciais de feijão-caupi. 2013. In: CONGRESSO BRASILEIRO DE ENGENHARIA AGRÍCOLA, 42., Anais. Fortaleza: SBEA, 2013. 3 p (CD-ROM).

Cardoso, M.J.; Melo, F.B.; Lima, M.G. Ecofisiologia e manejo de plantio. 2005. In: Freire Filho, F.R.; Lima, J.A.A.; Ribeiro, V.Q. (Ed.). Feijão-caupi: 
avanços tecnológicos. Brasília, DF: Embrapa Informação Tecnológica; Teresina: Embrapa Meio-Norte, Cap. 5. p. 211-228.

Capra, A., Scicolone, B. 2007. Recycling of poor quality urban wastewater by drip irrigation systems. Journal of Cleaner Production 5: 1529 1534.

Empresa Brasileira de Pesquisa Agropecuária. 2006. Sistema brasileiro de classificação de solos. 2.ed. EMBRAPA - Centro Nacional de Pesquisa de Solos, Rio de Janeiro, Brasil. 306 p.

Empresa Brasileira de Pesquisa Agropecuária. 2003. Sistema brasileiro de classificação de solos. 1.ed. EMBRAPA - Centro Nacional de Pesquisa de Solos, Rio de Janeiro, Brasil. 204 p.

Ferreira, V.M., Andrade Júnior, A.S., Cardoso, M.J., Ribeiro, V.Q., Morais, E.L.C. 2010. Performance produtiva do consórcio milho - feijão caupi e disponibilidade hídrica do solo. Revista Brasileira de Ciências Agrárias 5: 177-186.

Frizzone, J.A. 1992. Irrigação por aspersão: uniformidade e eficiência. ESALQ-Departamento de Engenharia Rural, Piracicaba, Brasil. 53 p.

Garcia, A.A.F.; Barbin, D.; Piedade, S.M.S. 2002. LCE 602: Estatística Experimental (aulas práticas). Piracicaba: ESALQ, 63p.

Gualter, R.M.R., Leite, L.F.C., Araújo, A.S.F., Alcântara, R.M.C.M., Costa, D.B. 2008. Inoculação e adubação mineral em feijão-caupi: efeitos na nodulação, crescimento e produtividade. Scientia Agraria 9: 469-474.

Machado, C.F., Teixeira, N.J.P., Freire Filho, F.R., Rocha, M.M., Gomes, R.L.F. 2008. Identificação de genótipos de feijão-caupi quanto à precocidade, arquitetura da planta e produtividade de grãos. Revista Ciência Agronômica 39: 114-123.

Matos Filho, C.H.A., Gomes, R.L.F., Rocha, M.M., Freire Filho, F.R., Lopes, A.C.A. 2009. Potencial produtivo de progênies de feijão-caupi com arquitetura ereta de planta. Ciência Rural 39: 348-354.

Mousinho, F.E.P., Andrade Júnior, A.S., Frizzone, J.A. 2008. Viabilidade econômica do cultivo irrigado do feijão-caupi no estado do Piauí. Maringá 30: 139-145.

Nogueira, M.C.S. 2007. Experimentação Agronômica l: conceitos, planejamento e análise estatística. Piracicaba: M. C. S. Nogueira, 479p.

Oliveira, G.A., Araújo, W.F., Cruz, P.L.S., Silva, W.L.M., Ferreira, G.B. 2011. Resposta do feijãocaupi as lâminas de irrigação e as doses de fósforo no cerrado de Roraima. Revista Ciência Agronômica 42: 872-882.
Pimentel-Gomes, F. Curso de estatística experimental. 2000. 14. ed. São Paulo, Livraria Nobel. 467p.

Santos, J.F. 2013. Produtividade de cultivares de feijão-caupi no agreste paraibano. Tecnol. \& Ciência Agropecuária 7: 31-36.

Santos, C.F., Lima, G.P.P., Morgado, L.B. 2010. Tolerância e caracterização bioquímica em feijão-caupi submetido a estresse hídrico na préfloração. Naturalia 33: 34-44.

Santos, J.F., Grangeiro, I.T.J., Brito, C., Santos, M.C.C.A. 2009. Produção e componentes produtivos de variedades de feijão-caupi na microrregião do Cariri Paraibano. Engenharia Ambiental 6: 214-222.

Souza, L.S.B., Moura, M.S.B., Sediyama, G.C., Silva, T.G.F. 2011. Eficiência do uso da água das culturas do milho e do feijão-caupi sob sistemas de plantio exclusivo e consorciado no semiárido brasileiro. Bragantia 70: 715-721.

Silva, J.A.L., Neves, J.A. 2011 . Componentes de produção e suas correlações em genótipos de feijão-caupi em cultivo de sequeiro e irrigado. Revista Ciência Agronômica 42: 702-713.

Tagliaferre, C., Santos, T.J., Santos, L.C., Santos Neto, I.J., Rocha, F.A., Paula, A. 2013. Características agronômicas do feijão-caupi inoculado em função de lâminas de irrigação e de níveis de nitrogênio. Rev. Ceres 60: 242-248.

Thornthwaite, C.W., Mather, J.R. 1955. The water balance. Centerton: Drexel Institute of Technology - Laboratory of Climatology. 104 p.

Zimmermann, F.J.P. Estatística aplicada à pesquisa agrícola. 2004. Santo Antônio de Goiás - GO: Embrapa Arroz e Feijão, 402p. 